\title{
Paisaje social de Lima
}

\author{
Wilfredo Kapsoli Escudero \\ Universidad Ricardo Palma \\ wckapsoli@hotmail.com
}

\section{Resumen}

La ciudad de Lima, desde su fundación (18 de enero de 1535) hasta la actualidad, ha experimentado una gradual transformación tanto en su estructura urbana como en su población. Este proceso, sin embargo, se hizo más rápido y hasta violento a partir de la década del 80 del siglo pasado por surgimiento y acción del Movimiento Revolucionario Túpac Amaru y de Sendero Luminoso. La década de la guerra de 1980 a 1990 desplazó poblaciones íntegras del campo a la ciudad, de modo tal que Lima terminó siendo la ciudad serrana más grande del país. Nosotros queremos, en esta oportunidad, referirnos a la composición social de Lima que aparece en las Tradiciones Peruanas de Ricardo Palma.

Palabras Clave: ciudad de Lima, transformación urbana, década del 80, Movimiento Revolucionario Túpac Amaru y de Sendero Luminoso, Ricardo Palma

\begin{abstract}
The city of Lima, since its foundation (January 18, 1535) to the present, has undergone a gradual transformation both in its urban structure and in its population. This process, however, became faster and even violent as of the 80s of the last century with the emergence and action of the Tupac Amaru Revolutionary Movement and the Shining Path. The decade of the war of 1980 to 1990 made complete populations move from the countryside to the city, in such a way that Lima ended up being the biggest city of the country with people from the mountains. We want, on this occasion, to refer to the social composition of Lima that appears in Ricardo Palma's Peruvian Traditions.
\end{abstract}

Keywords: city of Lima, urban transformation, Tupac Amaru Revolutionary Movement and the Shining Path PCP, Ricardo Palma. 
Wilfredo Kapsoli Escudero, Doctor en Historia en la Universidad Nacional Mayor de San Marcos - UNMSM, Licenciado en Educación, Especialidad de Matemáticas Universidad Nacional Mayor de San Marcos - UNMSM. Posee estudios de posgrado en la Escuela Práctica de Altos Estudios de París. Ha sido becado por la Comunidad Científica Japonesa en la Universidad Nanzan de Nagoya. Es docente de la Universidad Ricardo Palma. Ha sido director del Centro de Investigación de la Universidad Ricardo Palma. Es autor de diversos artículos en revistas especializadas y libros de investigación. 


\section{Introducción}

Sobre la antigua ocupación prehispánica gobernada por Taulichusco, los conquistadores españoles fundaron la ciudad de Lima, que sería la capital del Virreinato Peruano. En sus inicios fueron poquísimos los españoles que lo habitaron siendo menos los criollos y más los indios y los esclavos. Enfermedades desconocidas por la población nativa causaron una catástrofe demográfica acentuada en la costa, de modo tal que fue repoblado con la presencia masiva de los esclavos negros. Los gobernantes fomentaron entonces un racismo solapado a fin de que aquellos grupos subalternos no se unieran contra ellos, creando una rivalidad social que ha perdurado hasta la actualidad.

\section{Imagen de conjunto}

En distintos documentos y referencias bibliográficas, es comentado este tema en los diarios de Lima, en los viajeros extranjeros (por ejemplo: Lima y la Sociedad Peruana a mediados del siglo XIX de Max Radiguet e Imagen del Perú en el siglo XIX de Leonce Angrand) y diversos estudiosos contemporáneos como Lima apuntes históricos, descriptivos, estadístico y de costumbres de Manuel Atanasio Fuentes; así como Una Lima que se va de José Gálvez.

En la presente comunicación queremos destacar una tipología de los personajes anónimos y populares que aparecen en Las Tradiciones Peruanas de Ricardo Palma. Para el efecto contamos con el trabajo pionero del maestro Luis Alberto Sánchez titulado Don Ricardo Palma y Lima. En él sobresale particularmente el capítulo tercero: Lima en las Tradiciones Peruanas. Aquí hay una imagen general de la población capitalina resaltando personajes e instituciones como las Tapadas, los monjes, los aguateros, los esclavos, los indios y los criollos. 
El viajero francés Radiguet en su diario Lima y la sociedad peruana, había anotado al respecto un comentario general:

Si se quiere saber lo que hay en esa sociedad, aun en pleno siglo diecinueve, de gracia inimitable y de originalidad pintoresca, es a la vida diaria que hay que interrogar, es la existencia misma del limeño que hay que compartir de alguna manera, ya bajo el techo de su casa hospitalaria, ya en medio de esas fiestas de cada día, que dan a la capital del Perú un carácter tan encantador de esplendor y de animación jovial. Los recuerdos que nos ha dejado Lima. (1971:3)

Por su parte, Luis Alberto Sánchez reproduce un poema de Juan del Valle y Caviedes sobre la Santa Inquisición, que a la letra dice:

Descubrimiento.

He venido a descubrirme

del auto de fe el pregón que en el nacer hay delito

según donde se nació;

pues he venido encorozada

a una vieja muy feroz,

por nacida entre Alca y Huete...

icon la Inquisición, chitón!

(2015:60)

Seguidamente se enfatiza el destino final de las víctimas con la siguiente estrofa:

Ha muerto impenitente (según dicen);

y con sus huesos la candela aticen,

por lo que es justo que la hoguera enciendan

Mas, ioh dolor! Mis voces no la ofendan...

En su aplauso otras plumas se eternicen 
Y su causa las Cortes la defiendan

Requiescat in pace. Amén

(Op. Cit.: 61)

En cuanto al mundo de los esclavos, nuestro autor destaca:

La Santa Imagen de los negros angolas y mozambiques, adorada hoy día en las Nazarenas, se sobrepone a todas las acechanzas. En vano pintores, pagados especialmente, tratan de borrar el tabique que resistió al terremoto y que conservó intacta la sagrada efigie: el Señor castiga a los osados, paralizándoles el brazo que intentaba desfigurar o borrar la imagen... Y así se fue extendiendo el culto a todo el pueblo, y así cundió esa devoción que hasta ahora subsiste, dando a la ciudad típico aspecto en los días de octubre de cada año.

(Op. cit.: pág. 67)

Anteriormente, en relación a los esclavos y la religión, Max Radiguet hizo el siguiente comentario acerca de las cofradías de negros:

Aquí, como en todas partes, la naturaleza parece haber tratado a los negros como verdadera madrastra, negándoles dones físicos, y no concediéndoles los de la inteligencia, sino con una extrema parsimonia. Son siempre las mismas cabelleras lanudas, las mismas narices aplastadas, las mismas bocas toscas y avanzadas en hocico. Sin embargo, lejos de haberse viciado, todo anuncia que su raza se ha fortalecido en el suelo de su esclavitud. Casi todas las negras criollas, son más robustas que sus madres africanas. Desde el punto de vista moral, la suma de sus virtudes no equilibra la de sus vicios. Cuanto más libres son, más crueles, vengativos, ladrones y perezosos se muestran. Por el contrario, los que habitan en las ciudades, y viven bajo la mirada del amo, se 
vuelven siempre afables, honrados y fieles. Esos cambios se deben sin duda a la mansedumbre con la que los peruanos, en general, tratan a sus esclavos. En ese sentido, sus ancestros andaluces les han legado tradiciones de suavidad y humanidad, que sacaron ellos de la larga estadía de los moros en el sur de España; ellas se han perpetuado tanto en la generación actual que sorprende encontrar, en la vida íntima de ciertas familias, conexiones de amo a esclavo que se remontan, por los árabes, a los tiempos primitivos del Génesis. Una casa limeña no es, en cierto modo, sino la tienda de Abraham o de Jacob solidificada. Se ve ahí a los hijos de Bilha y de Zilpa, sirvientas de Lia y Raquel, recibir poco más o menos la misma educación que los hijos legítimos. La ley tampoco ha quedado atrás de las costumbres, ella protege al servidor contra la tiranía del amo y le da el derecho, sea de rescatarse directamente, sea de buscar un adquieren para su persona. El plazo en que debe de proveerse es de tres días; pasado ese plazo, sufre nuevamente la autoridad de su amo legal. Esta ley tan sabia ha dado lugar a asambleas de esclavos llamadas cofradías. Son especies de clubs donde los negros se reúnen más a menudo por grupos de la misma nacionalidad, y forman, por medio de cotizaciones voluntarias, un peculio destinado a sostener a la agrupación y asegurar a cada uno de sus miembros el libre ejercicio de la facultad que les reconoce la ley. Si un negro se subleva contra inicuos tratamientos, se presenta a la Cofradía donde expone sus agravios, y si no es lo bastante feliz para encontrar por sus propios medios, o por las diligencias de sus consocios, un nuevo amo, es raro que el tesorero común no pueda proporcionarle la suma necesaria para su rescate. Se vuelve, entonces, esclavo de la Cofradía, hasta que pueda liberarse de ella.

(1971: 77). 
Los esclavos encontraron en la institución de las Cofradías un espacio de libertad que les permitía de alguna manera manejarse de acuerdo a sus propias costumbres y mantenerse fuera de control, vigilancia e imposición de las creencias de sus amos.

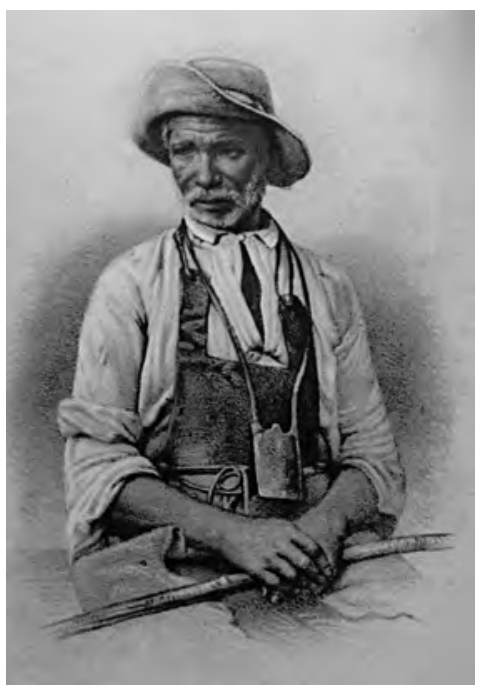

Fig. 1

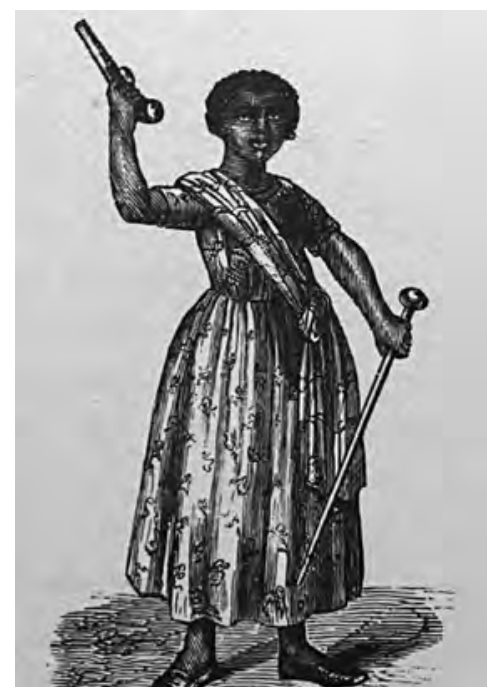

Fig. 2

Fuentes, 1985: 21 y 83.

Otros personajes sobresalientes en el mundo limeño fueron las Limeñas, que han merecido diversos comentarios e imágenes en las acuarelas y pinturas de la época, como las siguientes:

El epíteto español "bonita", está generalmente consagrado, cuando se habla de las limeñas. Se ven pocas, en efecto, que llegan a la hermosura pequeñas, más bien que grandes, son esbeltas y bien proporcionadas. En su rostro de rasgos regulares y finos, resaltan en medio de una palidez que no tiene nada de enfermiza, y bajo el arco regular de las cejas, ojos negros de una movilidad febril, y un poder de ojeadas, 
sin rival. Sus manos y sus pies, son su orgullo, tienen toda la perfección deseada. La limeña ha conservado para su pie una solicitud que, al comienzo de siglo, era llevada hasta la idolatría. Entonces, las mujeres, en su intimidad, no llevaban zapatos ni medias; se maquillaban el pie por completo, como entre nosotros el rostro. Hoy día, por poco que la naturaleza haya dado, atolondradamente, un largo un poco exagerado a esa extremidad, una mujer no titubea en sacrificarse a la dimensión; y se tortura con un calzado muy chico a la manera de las chinas.

(Op. cit.: 45)

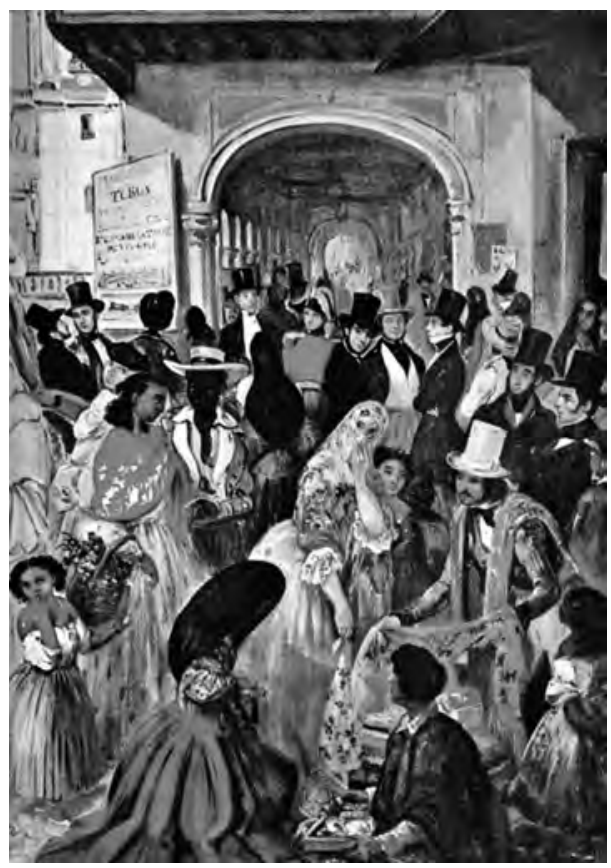

Fig. 3

Uno observa grupos atractivos con sus extraños trajes pintorescos, los que como adorno de la plaza ensamblan un cuadro de gran efecto.

Fuente: Rugendas: 1975: 138. 


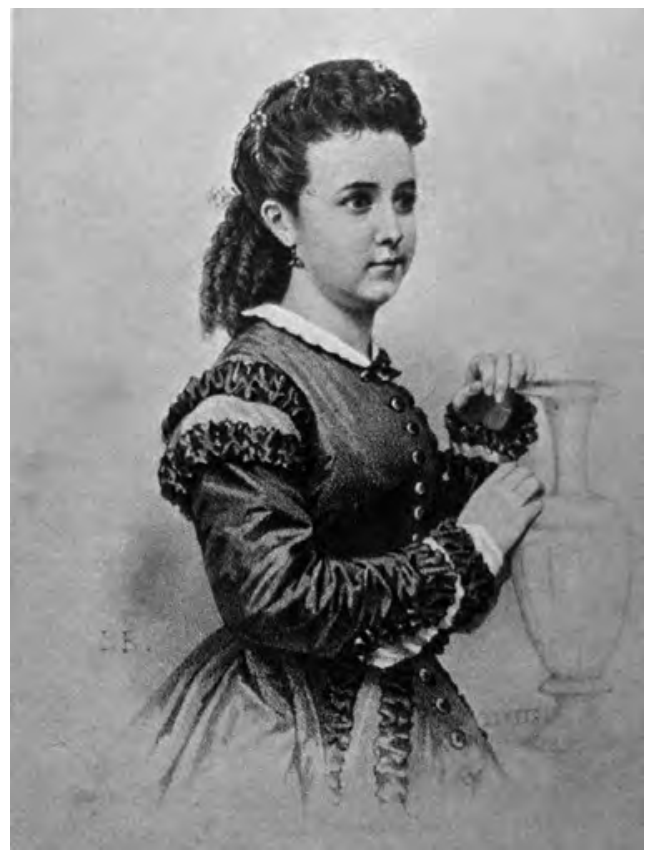

Fig. 4

Dama limeña del siglo XIX.

Fuentes, 1985: 39.

Dentro de las limeñas, las Tapadas adquieren una prestancia especial como lo precisa nuestro viajero francés:

El vestido de las limeñas ha sido descrito tan a menudo, que creemos inútil entrar en ese tema con lujo de detalles. Recordaremos solamente que la saya, o falda pegada, es ajustada al talle por medio de un pasador; fruncida sobre los riñones, y empujada, más abajo de la cintura por una prenda interior fuertemente engomada, se alza del cuerpo formando mil pliegues regulares. De ordinario la saya termina a la altura del tobillo y deja al descubierto un pequeño pie de línea muy aristocrática, calzado con medias 
color carne, y un zapato de raso blanco. La manta es un crespón de seda negra, del cual la limeña trae los dos lados sobre el rostro, de manera de velarlo por completo, dejando sin embargo a uno de sus ojos una abertura estrecha que sirve para dirigir la marcha. El chall es la parte más lujosa del vestido limeño; por poco que una mujer se jacte de elegante, ella no llevará sino crepé de la China cubierto de flores y follajes, tan sorprendente por la riqueza como por la maravillosa armonía de sus matices.

(Op. cit., pp 33-34)

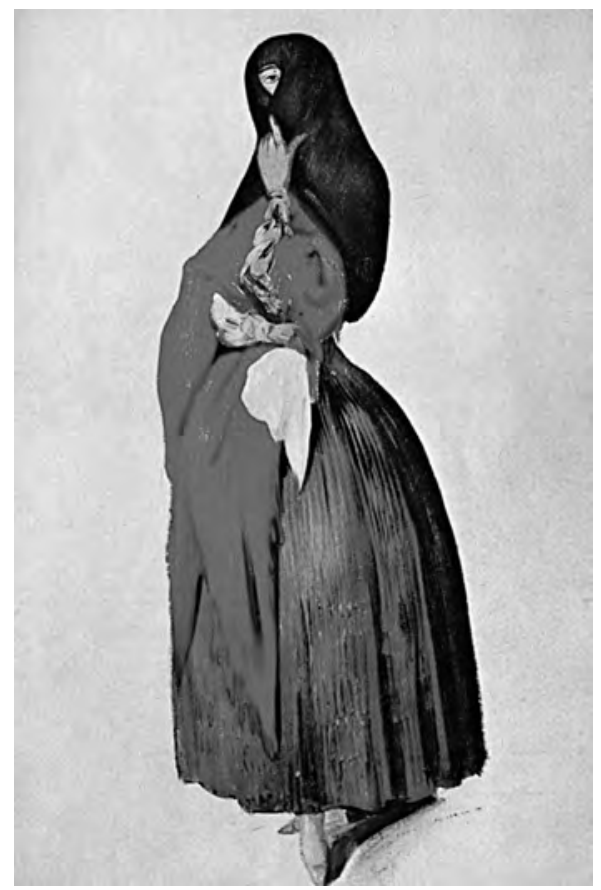

Fig. 5

Emboza la cabeza como una capucha, dejando solamente una abertura como de cucurucho de cuya profundidad el ojo relampagueante dispara sus rayos.

Fuente: Rudolf . Roeder, Viaje a Lima, pp. 103 


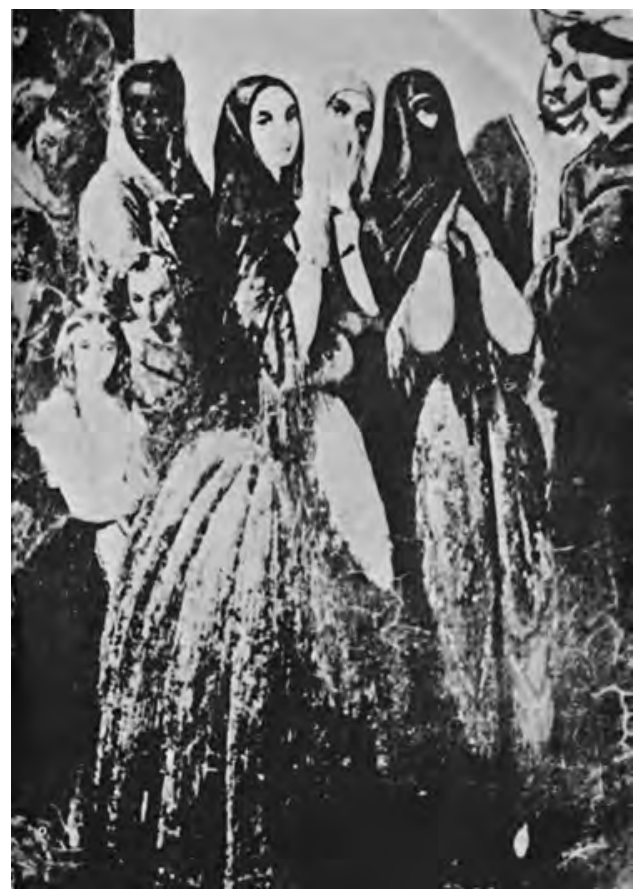

Fig. 6

Los sitios de reunión son preferentemente las iglesias. Fuente: Roeder, 1988: 105.

Las Tapadas continuaron vigentes durante gran parte del siglo XIX motivando modificaciones y detalles en sus vestuarios:

La primera tapada lleva la saya llamada orbegosina que empezó a usarse en 1834, siendo Presidente del Perú el General Orgeboso. También se la llamó saya salaverrina. La otra tapada lleva la saya verde o gamarrina que empezó a usarse desde 1829 por las limeñas partidarias del General Gamarra. La saya salaverrina (orbegosina) prevaleció hasta después de 1855 en que las modas francesas proscribieron la saya y manto, proscripción que ni excomuniones de un 
Concilio limense ni ordenanzas de varios virreyes habían logrado haber prácticas. (Kapsoli, 2014: 243).

Otro personaje representativo del mundo limeño en particular y del peruano en general, es la Rabona, de cuyo accionar nos enteramos por las siguientes anotaciones inteligentes:

El ejército peruano está compuesto, casi enteramente, por gente de color, que la "leva"; forma de reclutamiento militar usada en el país, reúne, a falta de noble vocación, en forma imprevista, bajo las banderas. Ahí reciben un sueldo, si no fantástico al menos muy regular, un equipo miserable, y son sometidos a un régimen alimenticio que solo su sobriedad puede aguantar. Las mujeres de los nuevos enrolados, llevando sus hijos y sus utensilios domésticos, los siguen entonces a sus guarniciones, y aún a sus campañas de guerra. Así, la mancha de un ejército peruano tiene todo el aspecto de esas tribus primitivas que van en busca de un nuevo territorio. Esas mujeres de los regimientos, esas rabonas, como las llaman en el Perú, agarran a los soldados con lazos que a pesar de ser ilegítimos no son por eso menos sólidos; ellas soportan sus brutalidades, comparten sus fatigas y sus miserias, sin repartir a veces la comida que han preparado, después de haberla conseguido a duras penas. La escolta de las rabonas ya es una garantía contra la deserción. Un soldado que puede llevar con él a la mujer querida no está atormentado por el deseo de reunírsele. Desafortunadamente las dulzuras que aportan a la vida del campo, la compañía de las rabonas no disminuye siempre el disgusto del soldado por el triste oficio que le imponen. (Radiguet, 1971: 71)

Juan Mauricio Rugendas, otro viajero del siglo XIX, también nos ha dejado comentarios e imágenes sobre la fiesta de San Juan Bautista en la pampa de Amancaes: 
... esta vez con multicolor poncho listado, gran sombrero alón, altas botas de cuero y dentadas y tintineantes espuelas en apoyo del viejo dicho: al mejor caballo, la mejor espuela. En primer plano hay dos negros, uno de extravagante indumentaria hecha de largo sacón azul y sombrero de copa, vendedor ambulante portando canasta con bebidas y, en la mano izquierda, atado; y el otro, caído en el suelo y dejando rodar cesta de naranjas por culpa de la estampida del solípedo azabache montando por garrida morena al sufrir el acoso del mofletudo cholo que, jinete en ágil zaino, trata de besarla. Al lado opuesto de la humorística escena, delante de balancín y pareja de jinetes, en medio de abigarrado grupo que preludía la jarana a todo dar, una pareja alerta a las notas de una tórrida zamacueca - ella una pimpante zamba con el clásico sombrero de torta, la saya rosa remangada descubriendo el fustán y en la diestra pañuelo desplegado, en actitud de hacer con los pies un redoble, y su contraparte de chaqueta blanca, pantalón azul y sombrero, con el usual pañuelo de payacate delante de sí y cogido por las puntas con ambas manos - sigue los compases del dúo formado por negro arpista y mestizo de chistera pulsando la guitarra (su croquis, así como el de la mujer, los hemos visto en Augsburgo). En este vital grupo y ya en primera fila, el intencionado y travieso pincel del pintor pone otro regocijante detalle: dos zambos calaveras discípulos de Baco cortejando a pareja de incautas jóvenes criollas, una de las cuales ya semiconsciente por los efectos de la turbadora bebida no solo se despatarra con la cabeza hacia atrás sino ha perdido ya un chapín... En la parte central, atrás, se ven los cobertizos de estera de las vivanderas, los que según era costumbre cuando expendíase chicha llevaban banderitas con los colores nacionales, tal como se aprecia en el cuadro. (1975: 50) 


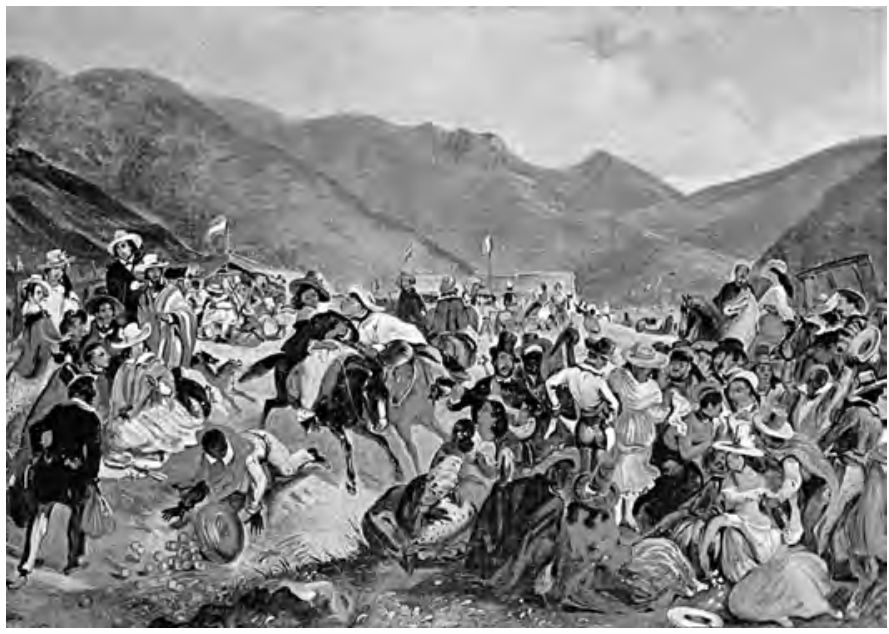

Fig. 7

Se reprocha a la vida en Lima una gran exuberancia, y más de uno la califica como la ciudad más viciosa de toda América.

Fuente: Rugendas, 1975: 147.

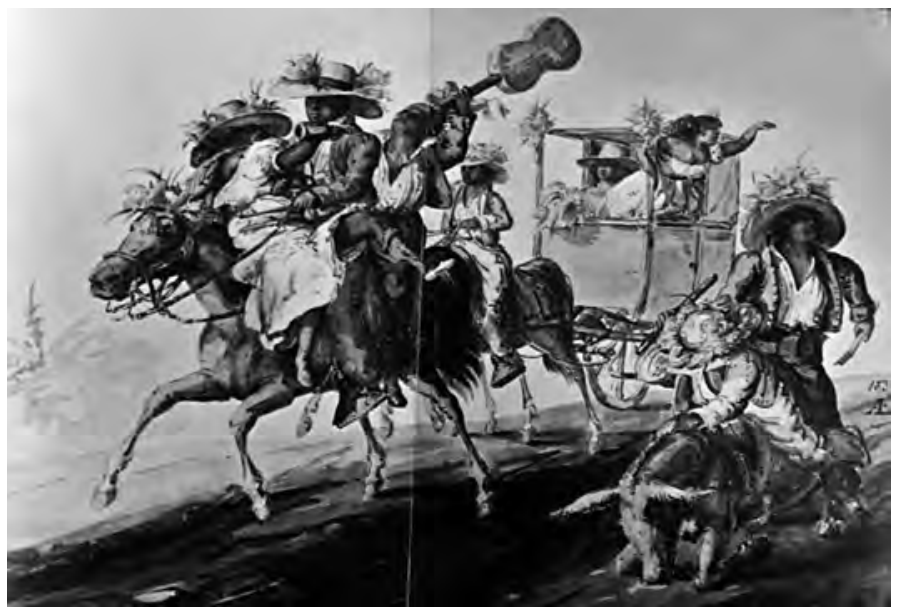

Fig. 8

Un retorno de la Fiesta de Amancaes.

Fuente: Angrand, 1972: 141-142. 


\section{Tipología de imágenes}

Don Ricardo Palma, en sus Tradiciones Peruanas ha retratado en ocasiones con ironía y sarcasmo a distintos personajes representativos del mundo colonial y republicano del Perú. Dentro de estos personajes tenemos, entre otros, a Santa Rosa de Lima, San Martín de Porres, Francisco Carbajal, la Perricholi, don Dimas de la Tijereta, los Caballeros de la Capa, el Negro León Escobar, Simón Bolívar y Ramón Castilla. En esta ocasión mostraremos rasgos y semblanzas de algunos de estos paradigmas que han motivado dos Tradiciones específicas.

\subsection{Don Dimas de la Tijereta}

Aquí destaca varias figuras, entre ellas: una doncella limeña, su tía, don Dimas y Lucifer. La primera, es presentada por don Ricardo con esta bellísima descripción:

Se enamoró hasta la coronilla de Visitación, gentil muchacha de veinte primaveras, con un palmito y un donaire y un aquel capaces de tentar al mismísimo general de los padres betlemitas, una cintura pulida y remonona de esas de mírame y no me toques, labios colorados como guindas, dientes como almendrucos, ojos como dos luceros y más matadores que espada y basto. iCuando yo digo que la moza era un pimpollo a carta cabal!. (Palma, 1946: 7)

Por otro lado, don Dimas de la Tijereta es descrito por nuestro autor como:

No embargante que el escribano era un abejorro recatado de bolsillo y tan pegado al oro de su arca como un ministro a la poltrona, y que en punto a dar no daba ni las buenas noches, se propuso domeñar a la chica a fuerza de agasajos; y ora la enviaba unas arracadas de diamantes con perlas 
como garbanzos, ora trajes de rico terciopelo de Flandes, que por aquel entonces costaban un ojo de la cara. Pero mientras más derrochaba Tijereta, más distante veía la hora en que la moza hiciese con él una obra de caridad, y esta resistencia traíalo al retortero. (1946: 7)

\section{La tía de Visitación es retratado como:}

...vieja como el pecado de gula, a quien años más tarde encorozó la Santa Inquisición por rufiana y encubridora, haciéndola pasear las calles en bestia de albarda, con chilladores delante y zurradores detrás. La maldita zurcidora de voluntades no creía, como Sancho, que era mejor sobrina mal casada que bien abarraganada; y endoctrinando pícaramente con sus tercerías a la muchacha, resultó un día que el pernil dejó de estarse en el garabato por culpa y travesura de un pícaro gato. Desde entonces si la tía fue el anzuelo, la sobrina, mujer completa ya según las ordenanzas de birlibirloque, se convirtió en cebo para pescar maravedíes a más de dos y más de tres acaudalados hidalgos de esta tierra. (Palma, Ricardo, loc. cit.)

Don Dimas, por conseguir el amor de Visitación, en un momento de desesperación exclamó:

iVenga un diablo cualquiera y llévese mi almilla en cambio del amor de esa caprichosa criatura!”. A esta invocación "Satanás, que desde los antros más profundos del infierno había escuchado las palabras del plumario, tocó la campanilla, y al reclamo se presentó el diablo Lilit. Por si mis lectores no conocen a este personaje, han de saberse que los demonógrafos, que andan a vueltas y tornas con las Clavículas de Salomón, libros que leen al resplandor de un carbunclo, afirman que Lilit, diablo de bonita estampa, muy zalamero y decidor, es el correvedile de Su Majestad Infernal. (Palma, Ricardo, loc. cit.) 


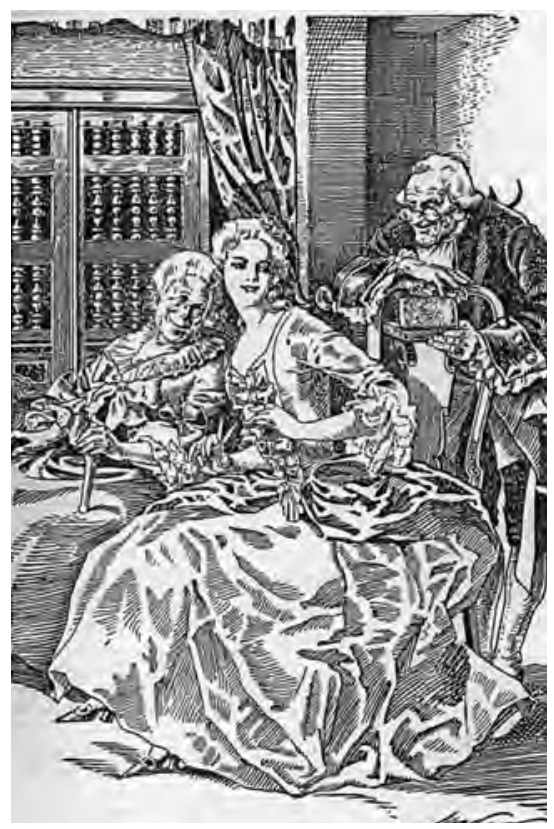

Fig. 9

Visitación, Don Dimas y la tía. Fuente: Palma, 1946, Tomo I: 9.

Como se conoce en esta tradición, Don Dimas vence al diablo por cuanto después de haber conseguido el amor de Visitación y gozado de ella por un tiempo, al cumplirse su pacto con el diablo, él ya en el infierno alegó que no había vendido su alma al diablo a favor de lo conseguido, sino su almilla (jubón cerrado, escotado y con medias mangas que se ponía debajo del pecho de los hombres como protector contra el frío).

\subsection{Un negro en el Sillón Presidencial}

A inicios de la República, Lima atravesó por una profunda crisis económico-social. Muchas actividades productivas y 
comerciales fueron afectadas y paralizadas durante las guerras por la independencia de nuestra patria. Los esclavos negros que habían luchado junto con las tropas patriotas en las batallas de Junín, Ayacucho y otras escaramuzas bélicas, no lograron la libertad ofrecida y añorada sino volvieron a los galpones para continuar privados de su libertad como en el mundo colonial. Por ello, las fugas, el vagabundaje y bandolerismo se expandieron violentamente cubriendo todo el entorno de la ciudad de Lima y sus alrededores. Por su parte, los patriotas, militares que lucharon por la independencia, se disputaron el poder entre ellos motivando una verdadera guerra civil. En estas condiciones mientras los soldados de Luis José de Orbegoso y de Felipe Santiago Salaverry luchaban por el poder, en las serranías del país el bandolero negro León Escobar tomó el sillón presidencial manteniéndose en el cargo por dos días.

José Ángel Bujanda estaba encargado de la seguridad del palacio de gobierno y “...para conservar el orden en la capital sólo disponía Bujanda de cuarenta soldados de caballería y de poco menos de cien infantes, a quienes estaba encomendado el servicio de policía en la ciudad, amagada por bandas de montoneros capitaneados por algún facineroso, las que mantenían en perpetua alarma al vecindario de los arrabales, haciendo disparos al aire, y al grito de iViva Orbegoso!".

Una mañana había salido Bujanda con los cuarenta jinetes a batir una montonera que merodeaba entre Surco y Miraflores, cuando a las doce del día se presentó en Malambo el famoso negro León Escobar, capitán de una cuadrilla de treinta bandidos los que a todo galope avanzaron desde San Lorenzo hasta la puerta de Palacio, en que la guardia constaba sólo de un teniente, un sargento y seis soldados, que no opusieron la más leve resistencia. Se constituyó León en el Salón de Palacio, estacionándose la montonera frente al atrio de la catedral y vitoreando estruendosamente a Orbegoso: 
El negro Escobar, arrellanado en el sillón Presidencial les brindó asiento en la que fue sala de ceremonias en tiempo de virreyes y los trató con toda cortesía, prometiéndoles que no autorizaría el menor desmán, siempre que la municipalidad, se aviniese a pagar un cupo de cinco mil pesos... en el término de dos horas, dinero que necesitaba para atender a las exigencias y manutención de su gente. (Op. Cit.:88-89).

Nuestro anecdótico personaje mereció sendas acuarelas de Pancho Fierro y además de otra ilustración que reproducimos para visualizar a este actor singular de nuestra historia social peruana.

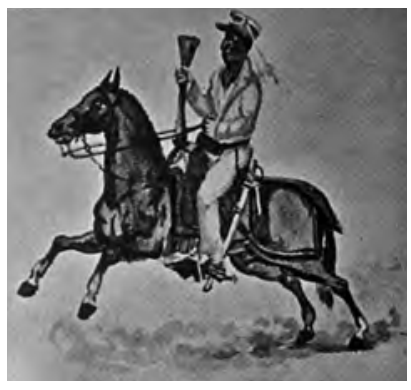

Fig. 10

Fuente: Aula Palma XIII, Kapsoli, 2014: 262.

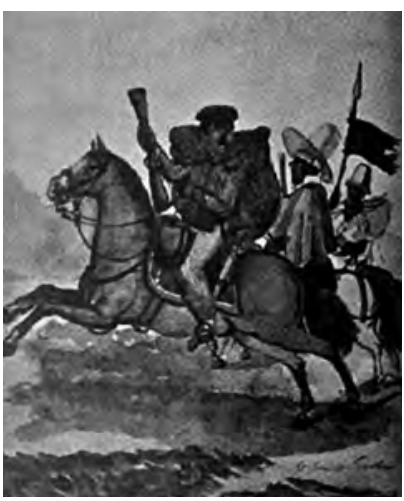

Fig. 11

Fuente: Aula Palma XIII, Kapsoli, 2014: 262. 


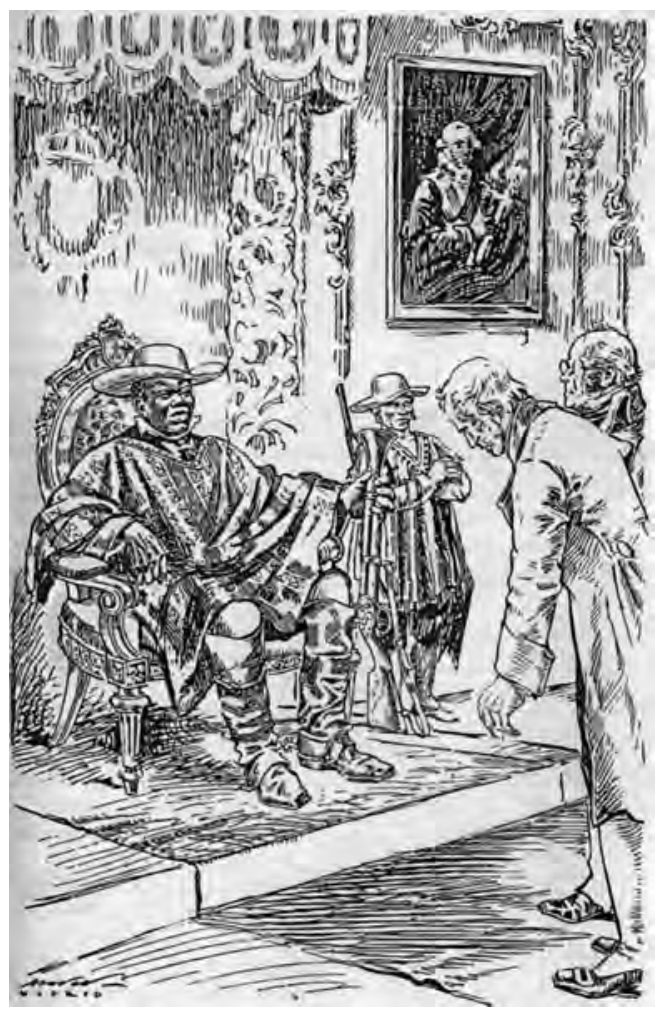

Fig. 12

"El negro Escobar, arellanado en el sillón". Fuente: Palma, 1946, Tomo V: 89. 


\section{Bibliografía}

Angrand, L. (1972). Imagen del Perú en el siglo XIX. Lima: Ed. Carlos Milla Batres.

Escobar, A. (2002). Ricardo Palma. Lima: Ed. URP.

Fuentes, M. A. (1985). Lima: apuntes históricos, descriptivos, estadísticos y de costumbres. Lima: Ed. Fondo del libro.

Kapsoli, W. (2014). "Apostillas de Ricardo Palma a las acuarelas de Pancho Fierro". En: Aula Palma N XIII. Lima, Ed. URP.

Palma, R. (1946). Tradiciones Peruanas. Tomos I-VI. Madrid: Ed. Calpe.

Radiguet, M. (1971). Lima y la Sociedad Peruana. Lima: Ed. Biblioteca Nacional del Perú.

Roeder, R. (1988). Journey to Lima 1845. Ed. Librerias ABC.

Rugendas, J. M. (1975). El Perú Romántico del siglo XIX. Lima: Ed. Carlos Milla Batres.

Sánchez, L. A. (2015). Don Ricardo Palma y Lima. Lima, Ed. URP.

Recibido el 24 de noviembre del 2017 Aceptado el 12 de diciembre del 2017 